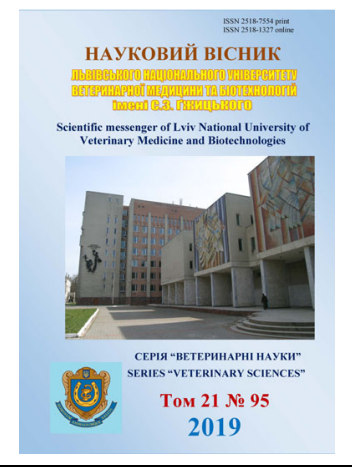

\author{
Науковий вісник Дьвівського національного університету \\ ветеринарної медицини та біотехнологій імені С.3. Гжицького. \\ Серія: Ветеринарні науки \\ Scientific Messenger of Lviv National University \\ of Veterinary Medicine and Biotechnologies. \\ Series: Veterinary sciences
}

\title{
The effects of falsification of meat of slaughtered animals with sodium hydrocarbonate on their quality and safety
}

\author{
N.M. Bogatko \\ Article info \\ Received 09.09.2019 \\ Received in revised form \\ 10.10.2019 \\ Accepted 11.10.2019 \\ Bilotserkivsky National Agrarian \\ University, Cathedral Square, 8/1. \\ Kyiv region, Bila Tserkva, \\ 09117, Ukraine. \\ Tel.: +38-067-395-21-50 \\ E-mail:nadiyabogatko@ukr.net
}

Bilotserkivsky National Agrarian University, Bila Tserkva, Ukraine

\begin{abstract}
Bogatko, N.M. (2019). The effects of falsification of meat of slaughtered animals with sodium hydrocarbonate on their quality and safety. Scientific Messenger of Lviv National University of Veterinary Medicine and Biotechnologies. Series: Veterinary sciences, 21(95), 66-74. doi: $10.32718 /$ nvlvet 9512
\end{abstract}

State monitoring is carried out to verify compliance with the requirements of the legislation on safety and individual indicators of food quality by market operators who produce meat and meat products, store (wholesale bases) and sell (agro-markets, supermarkets, etc.). When establishing a food hazard, the following conditions are taken into account: the usual conditions of use of the food by the consumer, each stage of its production, processing and circulation; information provided to the consumer, including labeling, including end-of-use (use) information, and other publicly available information on the avoidance of adverse health effects, food-related or food category the possible short- or long-term impact of the food on the health of the person consuming it and on future generations; possible cumulative toxicity effect. Therefore, it is important to develop simple, rapid methods for determining the adulteration of beef, pork, mutton, and meat of goat when carrying out risk-oriented controls on the sale of chilled and chilled meat in agri-food markets under different storage and marketing conditions. The falsification of chilled meat of slaughtered animals with a solution of sodium bicarbonate for 3-4 days of sale at temperatures from 0 to $6{ }^{\circ} \mathrm{C}$ was established: in beef and meat of goat - a weakly positive reaction (up to 5\%), in pork and mutton positive (5.1\% and more). Also falsification of meat of slaughtered animals with a solution of sodium bicarbonate on 17-18 (for beef) and 13-14 days of realization at temperatures from 0 to minus $1{ }^{\circ} \mathrm{C}$ was established: in beef, pork and meat of goat - a weak positive reaction (up to 5\%), positive in mutton (5.1\% or more). The technique of establishing adulteration was based on the use of an alcoholic solution of chrome dark blue with a mass concentration of $0.5 \%$, applied to the surface of the muscle tissue, and after 1-2 seconds, the presence of pale pink color was established - in the absence of meat processing with sodium bicarbonate or from light purple to dark purple in the presence of sodium bicarbonate depending on the amount of meat processed up to $5.0 \%$ and $5.1 \%$ or more. The results of the studies showed that the stability of the color intensity in the falsification of meat of slaughtered animals by treatment with sodium hydrogen carbonate was $99.9 \%$. The influence of sodium bicarbonate on the quality and safety of meat of slaughtered animals for 3-4 days of realization at temperatures $0-6{ }^{\circ} \mathrm{C}$ and $17-18$ (for beef) and 13-14 days of realization at temperatures from 0 to minus $1{ }^{\circ} \mathrm{C}$ has been established: the content of microorganisms in the superficial layers of muscle tissue decreased significantly $(P<0.01, P<0.001)$, and slightly increased slightly in the deep layers $(P<0.05)$; the $\mathrm{pH}$ was significantly $(P<0.001)$ increased and ranged from $6.45 \pm 0.023$ to $6.72 \pm 0.018 ;$ NMAOAM content tended to decrease, but the difference was not significant in the case of a weakly positive reaction (at temperatures of $0-6{ }^{\circ} \mathrm{C}$ in beef and meat of goat) and a slight decrease $(P<0.05)$ in pork and mutton (positive reaction); at temperatures from 0 to minus $1{ }^{\circ} \mathrm{C}, N M A O A M$ content tended to decrease, but a significant difference, except for beef (1.10 times, $(P<0.05)$, was not established: in pork -1.11 and meat of goat - 1.4 times, where the indicators slightly exceeded the limits of the standards of quality meat $\left(10^{3} \mathrm{CFU} / \mathrm{g}\right)$, respectively $-(9.89 \pm 2.65) \times 10^{2},(10.03 \pm 3.62) \times 10^{2}$ and $(10.4 \pm 2.29) \times 10^{2} \mathrm{CFU} / \mathrm{g}$, while in mutton (positive reaction) it decreased significantly by 1.05 times and was within the limits $-9.87 \pm 0.27 \times 10^{2} \mathrm{CFU} / \mathrm{g}$.

Key words: meat, beef, pork, mutton, meat of goat, safety, quality, express methods, testing, falsification, chrome dark blue, sodium bicarbonate. 


\title{
Вплив фальсифікації м'яса забійних тварин натрісм гідрокарбонатом на їх якість і безпечність
}

\author{
Н.М. Богатко
}

\author{
Білочерківський національний аграрний університет, м. Біла Церква, Украӥна
}

\begin{abstract}
Держсавний моніторинг проводиться з метою перевірки виконання вимог законодавства про безпечність та окремі показники якості харчових продуктів операторами ринку, які здійснюють виробництво м'яса та м'ясних продуктів, зберігають (оптові бази) та реалізують (агропродовольчі ринки, супермаркети тощо). Під час встановлення небезпечності харчового продукту враховуються: звичайні умови використання харчового продукту споживачем, кожна стадія його виробництва, переробки та обігу; інформація, надана споживачеві, зокрема про маркування включно з інформацією про дату кінцевого споживання (використання), та інша загальнодоступна споживачеві інформація про уникнення негативних для здоров'я наслідків, пов 'язаних з харчовим продуктом чи категорією харчових продуктів; можливий короткостроковий чи довгостроковий вплив харчового продукту на здоров'я людини, яка його споживає, та на майбутні покоління; можливий накопичувальний ефект токсичності. Тому важливо при здійсненні ризик-орієнтованого контролю за реалізаџії остиглого та охолодженого м'яса на агропродовольчих ринках за різних умов зберігання й реалізації - розробляти прості, експресні методики визначення фальсифікації яловичини, свинини, баранини, козлятини. Установлено фальсифікацію охолодженого м'яса забійних тварин розчином натрію гідрокарбонату на 3-4 добу реалізаиії за температури від 0 до $6{ }^{\circ} \mathrm{C}:$ у яловичині $і$ козлятині - слабопозитивну реакиію (до 5\%), у свинині й баранині позитивну (5,1\% $і$ більше). Також установлено фальсифікацію м'яса забійних тварин розчином натрію гідрокарбонату на 17-18 (для яловичини) і 13-14 добу реалізаиї за температури від 0 до мінус $1{ }^{\circ} \mathrm{C}:$ у яловичині, свинині й козлятині- слабопозитивну реакиію (до 5\%), у баранині позитивну $(5,1 \%$ і більше). Методика встановлення фальсифікації трунтувалася на застосуванні спиртового розчину хромового темно-синього з масовою концентрацією 0,5\%, що наносили на поверхню м'язової тканини, $i$ через 1-2 секунди встановлювали наявність блідо-рожевого кольору - за відсутності обробки м'яса гідрокарбонатом натрію або наявності від світло-фіолетового до темно-фіолетового кольору - за наявності гідрокарбонату натрію залежно від кількості за обробки м'яса до 5,0\% та 5,1\% більше. Результатами досліджень встановлено, ше стабільність показників інтенсивності кольору за фальсифікаиії м'яса забійних тварин обробкою розчином натрію гідрокарбонатом становила 99,9\%. Установлено вплив натрію гідрокарбонату на якість та безпечність м'яса забійних тварин на 3-4 добу реалізаиії за температури 0-6 ${ }^{\circ} \mathrm{C}$ та на 17-18 (для яловичини) $i$ на 13-14 добу реалізації за температури від 0 до мінус $1{ }^{\circ} \mathrm{C}$ : вірогідно $(P<0,01, P<0,001)$ зменшувався вміст мікроорганізмів у поверхневих шарах м'язової тканини, а у глибоких шарах дещо незначно вірогідно підвищувався $(P<0,05) ;$ величина $p H$ вірогідно $(P<0,001)$ підвишувалась і знаходилась в межах від 6,45 \pm 0,023 до 6,72 \pm 0,018; уміст МАФАнМ мав тендениію до зниження, але різниия була не вірогідною за слабопозитивної реакиії (за температури 0-6 ${ }^{\circ} \mathrm{C}$ у яловичині і козлятині) $i$ незначно вірогідне зниження $(P<0,05)$ у свинині і баранині (позитивна реакція); за температури від 0 до мінус $1{ }^{\circ} \mathrm{C}$ уміст МАФАнМ мав тенденцію до зниження, але вірогідної різниці, крім яловичини (y 1,10 рази, (P < 0,05), не було встановлено: у свинині - у 1,11 і козлятині - у 1,4 разу, де показники незначно перевищували межу нормативів доброякісного м'яса $\left(10^{3} \mathrm{KVO} / 2\right)$ відповідно $-(9,89 \pm 2,65) \times 10^{2},(10,03 \pm 3,62) \times 10^{2}$ $i(10,04 \pm 2,29) \times 10^{2} \mathrm{KVO/2;} \mathrm{а} \mathrm{у} \mathrm{баранині} \mathrm{(позитивна} \mathrm{реакиія)} \mathrm{значно} \mathrm{знижувався} \mathrm{у} 1,05$ рази і був в межах нормативів - 9,87 \pm $0,27 \times 10^{2} \mathrm{KYO} / 2$.
\end{abstract}

Ключові слова: м'ясо, яловичина, свинина, баранина, козлятина, безпека, якість, експрес-методи, апробація, фальсифікація, хромовий темно-синій, натрію гідрокарбонат.

\section{Вступ}

В Україні, як показує практика, для успішнішого управління якістю та безпечністю продуктів харчування перед впровадженням системи НАССР варто розробляти та впровадити програми-передумови (Rehlament № 852/2004). Вони є базовими умовами та комплексом дій, необхідних для підтримання у всьому харчовому ланцюгу гігієнічного довкілля, придатного для виробництва, оперування та постачання безпечних кінцевих харчових продуктів і безпечних харчових продуктів для споживання людиною. Система $H A C C P$ - не автономна програма, а частина більш загальної системи методів контролю. Без надійного підгрунтя, що складається, і програмпередумов, які включають належну практику виробництва $(G M P)$ та повинні бути запроваджені й підтримуватися належним чином, система $Н A C C P$ не зможе стати ефективним інструментом для гарантування виробництва безпечного м'яса забійних тварин (Hulebak \& Schlosser, 2012).

Однією із передумов $є$ захист харчових продуктів від сторонніх домішок та ризик-орієнтований конт- роль за процесами виробництва м'яса та м'ясопродуктів, а саме хімічного небезпечного чинника. Також за виробництва м'яса забійних тварин та ï обігу на сьогодні найбільш затребуваними, окрім $(G M P), \quad €$ належна гігієнічна практика (GHP) (Rehlament №178/2002). Фальсифікація м'яса та м'ясопродуктів $є$ соціальною проблемою. Внаслідок приховування неякісного та небезпечного харчового продукту трапляються порушення та недотримання санітарно-гігієнічних вимог під час виробництва, зберігання та обігу м'яса забійних тварин на потужностях з їх виробництва, оптових базах, агропродовольчих ринках, в супермаркетах.

Забезпечення населення високоякісними та безпечними харчовими продуктами, зокрема м'ясом забійних тварин - яловичиною, свининою, бараниною, козлятиною, вимагає здійснення фахівцями ветеринарної медицини належного державного контролю за принципами пріоритетності безпеки у питаннях життя і здоров'я людини перед будь-якими іншими інтересами та цілями у сфері діяльності операторів ринку. Орієнтований державний контроль грунтується на об'єктивності, неупередженості, відкритості, про- 
зорості, плановості та систематичності (Postanova Kabinetu Ministriv Ukrainy vid 31.10. 2018. № 896).

Свіже м'ясо забійних тварин (яловичина, свинина, баранина, козлятина) $є$ цінним харчових продуктом для пересічних споживачів. Тому здійснення належного державного контролю щодо санітарногігієнічних вимог під час виробництва, зберігання та реалізації м'ясної сировини здійснюється на всьому харчовому ланцюзі - від поля до столу (Dyrektyva Rady YeS 94/65/EC vid 14.12.1994 roku).

Оператори ринку України, які здійснюють виробництво, зберігання і реалізацію яловичини, свинини, баранини i козлятини, керуються нормативноправовими актами, що регламентують безпечність і якість м'яса забійних тварин, удосконалюють його норми безпечності та якості (Pravila peredzabijnogo veterinarnogo ogljadu tvarin..., 2002; DSTU 6030:2008; DSTU 7158:2010; HOST 1935-55).

Упродовж останніх років у роботах вітчизняних $\mathrm{i}$ закордонних авторів розглянуто окремі аспекти цієї актуальної проблеми щодо контролю безпечності та якості м'яса забійних тварин за виробництва м'ясної сировини, зберігання й реалізації (Mizobe et al., 2000). Важливе місце відводиться питанням санітарних заходів та умов, спрямованих на збереження якості м'яса забійних тварин і гарантування безпечності й придатності для споживання, а також контролю ризиків (Comaposada et al., 2000) на всіх етапах виробництва.

Одним із важливих хімічних ризиків за виробництва, зберігання та обігу м'яса забійних тварин є встановлення фальсифікації хімічними реагентами на його безпечність і якість. А тому нами був розроблений простий, ефективний, вірогідний експресний метод: визначення фальсифікації м'яса забійних тварин (яловичини, свинини, баранини, козлятини) за обробки розчином натрію гідрокарбонатом із застосуванням спиртового розчину хромового темно-синього з масовою концентрацією 0,5\% (Bohatko et al., 2019). В основу розроблення експресного методу було покладено завдання - визначити фальсифікацію м'яса забійних тварин (яловичини, свинини, баранини, козлятини) за обробки їх лужним розчином для довготривалого зберігання, усунення ознак псування та зменшення мікробного обсіменіння за допомогою використання індикатора спиртового розчину хромового темносинього, що забезпечить достовірність результатів за визначення безпечності та якості м'яса.

Метою роботи було встановити вплив фальсифікації м'яса забійних тварин за оброблення розчином натрію гідрокарбонату на його показники якості та безпечності.

Завданням дослідження було обгрунтувати доцільність використання розробленого експресного методу визначення фальсифікації м'яса забійних тварин за оброблення його розчином натрію гідрокарбонатом і визначити показники якості та безпечності яловичини, свинини, баранини, козлятини під час охолодження м'яса забійних тварин за температури від 0 до $6^{\circ} \mathrm{C}$ на 2 та 3-4 добу під час реалізації його на агропродо- вольчих ринках та за температури від 0 до мінус $1{ }^{\circ} \mathrm{C}$ упродовж 16 та 17-18 діб (для яловичини), упродовж 12 та 13-14 діб (для свинини, баранини, козлятини).

\section{Матеріал і методи досліджень}

Були проведені експериментальні дослідження щодо впливу хімічного реагенту натрію гідрокарбонату на якість та безпечність м'яса забійних тварин. Проби яловичини, свинини, баранини, козлятини були відібрані на агропродовольчих ринках Київської області й досліджені в умовах акредитованих Центральної випробувальної державної лабораторії Держпродспоживслужби в Київській області та м. Києві та лабораторії ветеринарно-санітарної експертизи, гігієни продукції тваринництва кафедри ветеринарносанітарної експертизи, гігієни продуктів тваринництва та патологічної анатомії імені Й.С. Загаєвського та кафедри ветеринарно-санітарної експертизи Інституту післядипломного навчання керівників і спеціалістів ветеринарної медицини Білоцерківського НАУ. Загальна кількість досліджуваних проб м'яса забійних тварин становила 243, із них: яловичини - 69, свинини -74 , баранини - 61, козлятини - 39. Відбір досліджуваних проб м'яса у кількості 200 г і підготовку їх до аналізування для оцінювання показників його якості та безпечності проводили відповідно до вимог "Правил передзабійного ветеринарного огляду тварин та ветеринарно-санітарної експертизи м'яса та м'ясних продуктів", ГОСТ 7269-2006. Показники якості та безпечності м'яса забійних тварин визначали згідно $з$ нормативними документами: органолептику за сенсорним випробуванням (колір, запах, вологість, проба варки) (HOST 7269-2006); величину рН потенціометричним методом за використання рН-метру за величиною концентрації водневих іонів (DSTU 2917 2001); кількість мікроорганізмів у 1 середньому полі зору визначали методом мікроскопії мазків-відбитків, пофарбованих за Грамом, у поверхневих та глибоких шарах м'язової тканини шляхом підрахунку кількості мікроорганізмів у 25 полях зору і подальшим вирахуванням на 1 поле зору (HOST 23392-2016); загальну кількість мікроорганізмів (МАФАнМ) - шляхом підрахунку кількості мікроорганізмів в 1 г м'ясі за посіву на агар для підрахунку колоній, який містить в своєму складі сухий ферментний гідролізат казеїну, сухий дріжджовий екстракт, безводну глюкозу, агар і воду, в чашки у термостаті за температури $(30 \pm 1){ }^{\circ} \mathrm{C}$ упродовж $(72 \pm 3)$ годин, і послідуючим підрахунком колоній (DSTU ISO 4833:2006).

Вперше був використаний розроблений експресний метод визначення фальсифікації м'яса забійних тварин (яловичини, свинини, баранини і козлятини) обробкою розчином натрію гідрокарбонату за допомогою спиртового розчину хромового темно-синього 3 масовою концентрацією 0,5\% (Bohatko et al., 2019). Метод грунтується на визначенні залишків розчину натрію гідрокарбонату на поверхні м'язової тканини площею розміром 2,0 × 2,5 см для усунення ознак псування та зменшення обсіменіння мікроорганізма- 
ми, на яку наносили градуйованою піпеткою 0,1 $0,2 \mathrm{~cm}^{3}$ спиртового розчину хромового темно-синього 3 масовою концентрацією $0,5 \%$ і через $1-2$ секунди встановлювали наявність блідо-рожевого кольору - за відсутності обробки м'яса натрію гідрокарбонатом (негативна реакція) або наявність від світлофіолетового до темно-фіолетового кольору - за наявності натрію гідрокарбонату відповідно до кількості за обробки м'яса до 5,0\% (слабопозитивна реакція) та $5,1 \%$ і більше (позитивна реакція).

\section{Результати та їх обговорення}

Законодавчою вимогою щодо виробництва, зберігання та обігу безпечного і якісного м'яса забійних тварин $\epsilon$ регламентування здійснення державного моніторингу, який проводиться компетентним органом 3 метою визначення пріоритетних напрямків державної політики у сфері харчових продуктів, розроблення заходів 3 недопущення обігу небезпечних харчових продуктів, визначення загального рівня забруднення хімічними реагентами (Pro derzhavnyi kontrol..., 2017). Тому для запобігання фальсифікації м'яса забійних тварин розчином натрію гідрокарбонату нами була розроблена та запатентована експресна методика і проведені випробування.

М'ясо забійних тварин, що реалізувалося на агропродовольчих ринках, було досліджене в різні терміни реалізації: відразу після забою худоби (остигле), яке піддавалося після розділення туш охолодженню до температури не вище ніж $12{ }^{\circ} \mathrm{C}$ : поверхня м'яса мала кірочку підсихання, запах специфічний для даного виду тварин, без сторонніх запахів, консистенція пружна, колір яловичини, баранини - темночервоний, козлятини - яскраво-червоний, свинини блідо-рожевий. За пробою варіння яловичина, свинина, баранини і козлятини відповідало свіжому ступеню. Дослідження також були проведені під час охолодження м'яса забійних тварин за температури від 0 до $6{ }^{\circ} \mathrm{C}$ на 2 та 3-4 добу під час реалізації його на агропродовольчих ринках та за температуривід 0 до мінус $1{ }^{\circ} \mathrm{C}$ упродовж 16 та 17-18 діб (для яловичини), упродовж 12 та 13-14 діб (для свинини, баранини, козлятини).

Органолептична оцінка охолодженого м'яса забійних тварин за температури від 0 до $6{ }^{\circ} \mathrm{C}$ на 2 добу і за температури від 0 до мінус $1{ }^{\circ} \mathrm{C}$ упродовж 16 та 12 діб відповідала свіжому ступеню. А органолептична оцінка сумнівного ступеня свіжості була в охолодженому м'ясі забійних тварин за температури від 0 до $6^{\circ} \mathrm{C}$ на 3-4 добу і за температури від 0 до мінус $1{ }^{\circ} \mathrm{C}$ упродовж 17-18 і 13-14 добу: поверхня м'язової тканини ослизнена, ледь липка, запах слабокислий, консистенція менш пружна, колір тьмяний, темно-червоний, а у свинини - сіро-рожевий; за проби варіння - помутніння бульйону, неприємний запах.
У таблиці 1 наведені дані щодо показників якості та безпечності м'яса забійних тварин у різні терміни їх реалізації на агропродовольчих ринках за негативної реакції на встановлення фальсифікації натрієм гідрокарбонатом.

Аналізуючи таблицю 1, варто зазначити, що в досліджуваних пробах остиглого та охолодженого м'яса забійних тварин за температури від 0 до $6{ }^{\circ} \mathrm{C}$ на 2 добу і за температури від 0 до мінус $1{ }^{\circ} \mathrm{C}$ на 16 добу (яловичина) і на 12 добу (свинина, баранина, козлятина), які за показниками відповідали свіжому ступеню, не виявлено фальсифікації натрієм гідрокарбонатом (негативна реакція). Аналогічно, в охолодженому м'ясі забійних тварин за реалізації на агропродовольчих ринках за температури від 0 до $6{ }^{\circ} \mathrm{C}$ на 3-4 добу та за температури від 0 до мінус $1{ }^{\circ} \mathrm{C}$ на $17-18$ добу (яловичина) і на 13-14 добу (свинина, баранина, козлятина), які за показниками відповідали сумнівному ступеню свіжості, також не виявлено фальсифікації натрієм гідрокарбонатом (негативна реакція). Негативна реакція у разі виявлення фальсифікації м'яса забійних тварин характеризувалася появою блідорожевого кольору за використання спиртового розчину хромового темно-синього 3 масовою концентрацією $0,5 \%$.

Згідно $з$ даними таблиці 1 було встановлено, що в охолодженому м'ясі на 3-4 добу реалізації за температури 0-6 ${ }^{\circ} \mathrm{C}$ вірогідно збільшувалося кількість мікроорганізмів у поверхневих і глибоких шарах м'язової тканини щодо показників на 2 добу відповідно: в яловичині - у 4,67 разу $(\mathrm{P}<0,001)$ i 4,20 рази $(\mathrm{P}<0,001)$; свинині - у 3,7 разу $(\mathrm{P}<0,001)$ і 2,38 разу $(\mathrm{P}<0,001)$; баранині - у 4,33 разу $(\mathrm{P}<0,001)$ і 3,43 разу $(\mathrm{P}<0,001)$; козлятині - у 3,20 разу $(\mathrm{P}<0,001) \mathrm{i}$ 3,83 разу $(\mathrm{P}<0,001)$. Вірогідні значення $(\mathrm{P}<0,001)$ зменшення величини $p H$ були отримані за дослідження за вищевказаних умов реалізації: у яловичині - у 1,03 разу, свинині - у 1,04, баранині - у 1,05 і козлятині - у 1,04 разу.

За недотримання санітарно-гігієнічних вимог і термінів реалізації м'яса відбувається його псування, накопичення летких жирних сполук, сірководню, аміаку і збільшення вмісту мезофільних аеробних та факультативно анаеробних мікроорганізмів (Ivchenko et al., 2006). Тому в охолодженому м'ясі забійних тварин на 3-4 добу реалізації за температури 0-6 ${ }^{\circ} \mathrm{C}$ вміст КМАФАнМ вірогідно збільшувався (Р $<0,001)$, щодо показників на 2 добу відповідно: в яловичині - у 1,44 разу, свинині - у 1,35, баранині - у 1,37 , козлятині - у 1,55 разу. Найбільше обсіменіння мікроорганізмами відзначалося за температури $0-6{ }^{\circ} \mathrm{C}$ в охолодженій свіжій свинині на 2 добу $(8,23 \pm 0,11) \times 10^{2} \mathrm{KУО} / \Gamma$ та на $3-4$ добу у сумнівної свіжості - $(11,09 \pm 0,026) \times 10^{2} \mathrm{KУO} / \Gamma$ (за норми $\left.10^{3} \mathrm{KУO} / г\right)$. 


\section{Таблиця 1}

Показники безпечності та якості м'яса забійних тварин у різні терміни їх реалізації на агропродовольчих ринках за негативної реакції на встановлення фальсифікації натрієм гідрокарбонатом, $\mathrm{M} \pm \mathrm{m}, \mathrm{n}=181$

\begin{tabular}{|c|c|c|c|c|}
\hline \multirow[b]{3}{*}{$\begin{array}{c}\text { Вид м’яса забійних } \\
\text { тварин }\end{array}$} & \multicolumn{4}{|c|}{ Показники безпечності і якості м’яса забійних тварин } \\
\hline & \multicolumn{4}{|c|}{ Назва показника м’яса } \\
\hline & $\begin{array}{c}\text { кількість мікроорганізмів у } \\
1 \text { середньому полі зору у } \\
\text { поверхневих/та глибоких } \\
\text { шарах м'язів }\end{array}$ & Величина $p H$ & $\begin{array}{c}\text { Кількість МАФАнМ, } \\
\text { КУО/Г }\end{array}$ & $\begin{array}{c}\text { Фальсифікація } \\
\text { м'яса розчином } \\
\text { натрію гідрокар- } \\
\text { бонатом }\end{array}$ \\
\hline \multicolumn{5}{|c|}{ Остигле м'ясо забійних тварин ( температура в товщі м’яса $\left.11-12{ }^{\circ} \mathrm{C}\right)$} \\
\hline Яловичина, $\mathrm{n}=12$ & $\frac{4 \pm 1}{6 \pm 1}$ & $5,88 \pm 0,028$ & $(0,68 \pm 0,15) \times 10$ & негативна \\
\hline Свинина, $\mathrm{n}=13$ & $\frac{3 \pm 1}{8 \pm 1}$ & $5,90 \pm 0,022$ & $(0,59 \pm 0,14) \times 10$ & негативна \\
\hline Баранина, $\mathrm{n}=11$ & $\frac{5 \pm 1}{9 \pm 1}$ & $6,08 \pm 0,018$ & $(0,72 \pm 0,08) \times 10$ & негативна \\
\hline Козлятина, $\mathrm{n}=6$ & $\frac{3 \pm 1}{7 \pm 1}$ & $5,92 \pm 0,026$ & $(0,81 \pm 0,09) \times 10$ & негативна \\
\hline \multicolumn{5}{|c|}{ Охолоджене м'ясо забійних тварин за температури від 0 до $6{ }^{\circ} \mathrm{C}$ на 2 добу } \\
\hline Яловичина, $\mathrm{n}=9$ & $\frac{3 \pm 1}{5 \pm 1}$ & $5,82 \pm 0,024$ & $(7,12 \pm 0,09) \times 10^{2}$ & негативна \\
\hline Свинина, $\mathrm{n}=8$ & $\frac{4 \pm 1}{8 \pm 1}$ & $5,81 \pm 0,031$ & $(8,23 \pm 0,11) \times 10^{2}$ & негативна \\
\hline Баранина, $\mathrm{n}=6$ & $\frac{3 \pm 1}{7 \pm 1}$ & $5,92 \pm 0,025$ & $(7,88 \pm 0,13) \times 10^{2}$ & негативна \\
\hline Козлятина, $\mathrm{n}=5$ & $\frac{5 \pm 1}{6 \pm 1}$ & $5,85 \pm 0,021$ & $(6,82 \pm 0,09) \times 10^{2}$ & негативна \\
\hline \multicolumn{5}{|c|}{ Охолоджене м'ясо забійних тварин за температури від 0 до $6{ }^{\circ} \mathrm{C}$ на 3-4 добу } \\
\hline Яловичина, $\mathrm{n}=7$ & $\frac{14 \pm 1^{* * *}}{21 \pm 1^{* * *}}$ & $5,64 \pm 0,021 * * *$ & $(10,25 \pm 0,18) \times 10^{2 * * *}$ & негативна \\
\hline Свинина, $\mathrm{n}=8$ & $\frac{15 \pm 1}{19 \pm * *} * * *$ & $5,61 \pm 0,030 * * *$ & $(11,09 \pm 0,26) \times 10^{2 * * *}$ & негативна \\
\hline Баранина, $\mathrm{n}=6$ & $\frac{13 \pm 1}{24 \pm 1^{* * *}}$ & $5,65 \pm 0,023 * * *$ & $(10,78 \pm 0,21) \times 10^{2 * * *}$ & негативна \\
\hline Козлятина, $\mathrm{n}=6$ & $\frac{16 \pm 1^{* * *}}{23 \pm 1^{* * *}}$ & $5,60 \pm 0,019 * * *$ & $(10,57 \pm 0,22) \times 10^{2 * * *}$ & негативна \\
\hline \multicolumn{5}{|c|}{ Охолоджене м’ясо забійних тварин за температури від 0 до мінус $1^{\circ} \mathrm{C}$} \\
\hline $\begin{array}{l}\text { Яловичина на } 16 \text { добу, } \\
\mathrm{n}=12 \text { (свіже м'ясо) }\end{array}$ & $\frac{4 \pm 1}{9 \pm *}+1^{* * *}$ & $5,87 \pm 0,017 * * *$ & $(7,25 \pm 0,21) \times 10^{2}$ & негативна \\
\hline $\begin{array}{l}\text { Яловичина на } 17-18 \\
\text { добу, } \mathrm{n}=12 \text { (сумнів- } \\
\text { ної свіжості) }\end{array}$ & $\frac{12 \pm 1}{18 \pm 1^{* * *}} *$ & $5,61 \pm 0,017 * * *$ & $(10,88 \pm 0,24) \times 10^{2 * * *}$ & негативна \\
\hline $\begin{array}{l}\text { Свинина на } 12 \text { добу, } \\
\mathrm{n}=13 \text { (свіже м'ясо) }\end{array}$ & $\frac{5 \pm 1 * * *}{7 \pm 1 * * *}$ & $5,90 \pm 0,015^{* * *}$ & $(6,09 \pm 0,17) \times 10^{2}$ & негативна \\
\hline $\begin{array}{l}\text { Свинина на } 13-14 \\
\text { добу, n }=13 \text { (сумнів- } \\
\text { ної свіжості) }\end{array}$ & $\frac{15 \pm 1}{21 \pm 1^{* * *}}$ & $5,63 \pm 0,018 * * *$ & $(11,12 \pm 0,28) \times 10^{2 * * *}$ & негативна \\
\hline $\begin{array}{l}\text { Баранина на } 12 \text { добу, } \mathrm{n} \\
=11 \text { (свіже м'ясо) }\end{array}$ & $\frac{4 \pm 1^{* * *}}{6 \pm 1^{* * *}}$ & $5,86 \pm 0,021 * * *$ & $(6,78 \pm 0,20) \times 10^{2}$ & негативна \\
\hline $\begin{array}{l}\text { Баранина на } 13-14 \\
\text { добу, n = } 11 \text { (сумнів- } \\
\text { ної свіжості) }\end{array}$ & $\frac{14 \pm 1^{* * *}}{18 \pm 1^{* * *}}$ & $5,67 \pm 0,021 * * *$ & $(10,36 \pm 0,21) \times 10^{2 * * *}$ & негативна \\
\hline $\begin{array}{l}\text { Козлятина на } 12 \text { добу, } \\
\mathrm{n}=6 \text { (свіже м'ясо) }\end{array}$ & $\frac{3 \pm 1}{8 \pm 1^{* *} *}$ & $5,87 \pm 0,019^{* * *}$ & $(5,98 \pm 0,14) \times 10^{2}$ & негативна \\
\hline $\begin{array}{l}\text { Козлятина на } 13-14 \\
\text { добу, } \mathrm{n}=6 \text { (сумнівної } \\
\text { свіжості) }\end{array}$ & $\frac{10 \pm 1^{* * *}}{17 \pm 1^{* * *}}$ & $5,62 \pm 0,022 * * *$ & $(10,43 \pm 0,23) \times 10^{2 * * *}$ & негативна \\
\hline
\end{tabular}

Примітки: ***-P $<0,001$

Також варто зазначити, що в охолодженій яловичині на 17-18 добу за температури від 0 до мінус $1{ }^{\circ} \mathrm{C}$ виявляли вірогідне збільшення кількості мікроорганізмів у поверхневих і глибоких шарах м'язів порівняно 3 показниками на 16 добу реалізації відповідно: у 3
$(\mathrm{P}<0,001)$ та 2 рази $(\mathrm{P}<0,001)$. В охолодженому м'ясі забійних тварин на 13-14 добу відмічається вірогідне збільшення кількості мікроорганізмів у поверхневих i глибоких шарах м'язів порівняно 3 показниками на 12 добу реалізації відповідно: у сви- 
нині - в 3 рази $(\mathrm{P}<0,001)$ і 3,01 разу $(\mathrm{P}<0,001)$, баранині - у $3,5(\mathrm{P}<0,001)$ та 3 рази $(\mathrm{P}<0,001)$ і козлятині - у 3,3 $(\mathrm{P}<0,001)$ та 2,13 разу $(\mathrm{P}<0,001)$. Величина $p H$ також у охолодженому м'ясі забійних тварин на 17-18 і 13-14 добу реалізації відносно показників на 16 і 12 добу зменшувалась вірогідно $(\mathrm{P}<0,001)$ у кислу сторону: в яловичині та свинині - у 1,05 разу, баранині - у 1,03 разу, козлятині - у 1,04 разу.

У разі порушення умов зберігання в м'ясі порушуються реакції глікогенолізу нагромаджуються проміжні та кінцеві продукти білкового обміну у вигляді амінів, амідів кислот, аміаку та інших сполук, неприємний запах (Kononskyi, 2006). У м'ясі також розвивається ряд незворотних біохімічних змін, що роблять його непридатним до споживання. Таким чином, в м'ясі відбуваються процеси глибокого авто- лізу - розпаду клітин м'яса за дії власних лізосомних і мікробних ферментів з утворенням отруйних сполук. Характерною ознакою псування м'яса $\epsilon$ підвищення кількості МАФАнМ (Tsekhmistrenko \& Tsekhmistrenko, 2014). Виявлено, що вміст МАФАнМ у м'ясі забійних тварин також вірогідно значно збільшувався $(\mathrm{P}<0,001)$ у ці терміни реалізації (на 17-18 і 1314 добу) порівняно з показниками на 16 i 12 добу відповідно: в яловичині - у 1,50 рази, свинині - у 1,83, баранині - у 1,53, козлятині - у 1,74 разу.

У таблиці 2 наведені дані щодо показників якості та безпечності м'яса забійних тварин у різні терміни їхньої реалізації на агропродовольчих ринках за позитивної та слабопозитивної реакцій на встановлення фальсифікації натрієм гідрокарбонатом.

\section{Таблиця 2}

Показники безпечності та якості охолодженого м'яса забійних тварин у різні терміни їхньої реалізації на агропродовольчих ринках за позитивної реакції на встановлення фальсифікації натрієм гідрокарбонатом, $\mathrm{M} \pm \mathrm{m}, \mathrm{n}=62$

\begin{tabular}{|c|c|c|c|c|}
\hline \multirow[b]{3}{*}{$\begin{array}{c}\text { Вид м’яса } \\
\text { забійних } \\
\text { тварин }\end{array}$} & \multicolumn{4}{|c|}{ Показники безпечності і якості м'яса забійних тварин } \\
\hline & \multicolumn{4}{|c|}{ Назва показника м’яса } \\
\hline & $\begin{array}{l}\text { кількість мікроорганіз- } \\
\text { мів у } 1 \text { середньому полі } \\
\text { зору поверхневих/та } \\
\text { глибоких шарах м'язової } \\
\text { тканини }\end{array}$ & Величина $p H$ & $\begin{array}{c}\text { Кількість } \\
\text { МАФАнМ, } \\
\text { КУО/г }\end{array}$ & $\begin{array}{c}\text { Фальсифікація м’яса } \\
\text { розчином натрію } \\
\text { гідрокарбонаттом }\end{array}$ \\
\hline \multicolumn{5}{|c|}{ Охолоджене м'ясо забійних } \\
\hline Яловичина, $\mathrm{n}=5$ & $\frac{9 \pm 1}{22 \pm 1}^{* *}$ & $6,56 \pm 0,020 * * *$ & $(10,02 \pm 0,26) \times 10^{2}$ & слабопозитивна \\
\hline Свинина, $\mathrm{n}=6$ & $\frac{8 \pm 1 * * *}{23 \pm 1 *}$ & $6,61 \pm 0,024 * * *$ & $(9,92 \pm 0,25) \times 10^{2 *}$ & позитивна \\
\hline Баранина, $\mathrm{n}=5$ & $\frac{7 \pm 1}{27 \pm 1} *$ & $6,65 \pm 0,021 * * *$ & $(9,99 \pm 0,24) \times 10^{2 *}$ & позитивна \\
\hline Козлятина, $\mathrm{n}=4$ & $\frac{10 \pm 1}{24 \pm 1}^{* * *}$ & $6,45 \pm 0,023 * * *$ & $(10,05 \pm 0,27) \times 10^{2}$ & слабопозитивна \\
\hline \multicolumn{5}{|c|}{ Охолоджене м’ясо забійних тварин за температури від 0 до мінус $1{ }^{\circ} \mathrm{C}$} \\
\hline $\begin{array}{l}\text { Яловичина на } 17- \\
18 \text { добу, } \mathrm{n}=12\end{array}$ & $\frac{9 \pm 1}{19 \pm 1} * * *$ & $6,57 \pm 0,017 * * *$ & $(9,89 \pm 0,25) \times 10^{2 *}$ & слабопозитивна \\
\hline $\begin{array}{l}\text { Свинина на 13-14 } \\
\text { добу, } \mathrm{n}=13\end{array}$ & $\frac{10 \pm 1 * *}{22 \pm 1 * *}$ & $6,72 \pm 0,018^{* * *}$ & $(10,03 \pm 0,28) \times 10^{2}$ & слабопозитивна \\
\hline $\begin{array}{l}\text { Баранина на 13-14 } \\
\text { добу, } \mathrm{n}=11\end{array}$ & $\frac{8 \pm 1}{20 \pm 1 * *}$ & $6,85 \pm 0,021 * * *$ & $(9,87 \pm 0,27) \times 10^{2}$ & позитивна \\
\hline $\begin{array}{l}\text { Козлятина на 13- } \\
14 \text { добу, } \mathrm{n}=6\end{array}$ & $\frac{7 \pm 1}{21 \pm 1} *$ & $6,53 \pm 0,022 * * *$ & $(10,04 \pm 0,29) \times 10^{2}$ & слабопозитивна \\
\hline
\end{tabular}

Аналізуючи таблицю 2, варто зазначити, що в досліджуваних пробах охолодженого м'яса забійних тварин за температури від 0 до $6{ }^{\circ} \mathrm{C}$ на 3-4 добу і за температури від 0 до мінус $1{ }^{\circ} \mathrm{C}$ на 17-18 добу (яловичина) і на 13-14 добу (свинина, баранина, козлятина) за фальсифікації натрієм гідрокарбонатом органолептичні показники були дещо погіршені: темночервоного кольору (яловичина, баранина, козлятина) i сіро-рожевого кольору (свинина), суха кірочка підсихання, запах затхлий, консистенція менш пружна, за проби варіння - помутніння бульйону, неприємний запах. За використання спиртового розчину хромового темно-синього 3 масовою концентрацією 0,5\% позитивна реакція на виявлення фальсифікації м'яса забійних тварин характеризувалася появою світло- фіолетового кольору (наявність фальсифікації натрію гідрокарбонатом нанесенням до 5,0\%), а слабопозитивна - темно-фіолетового кольору (наявність фальсифікації натрію гідрокарбонатом нанесенням 5,1\% і більше).

Встановлено (табл. 2), що за обробки охолодженого м'яса натрієм гідрокарбонатом кількість мікроорганізмів на 3-4 добу реалізації за температури 0-6 ${ }^{\circ} \mathrm{C}$ у поверхневих шарах м'язів порівняно з показниками сумнівної свіжості м'яса, яке мало негативну реакцію на виявлення натрію гідрокарбонату, вірогідно знизилася: у яловичині - у 1,56 рази ( $\mathrm{P}<0,01)$, свинині - у $1,87$ ( $\mathrm{P}<0,001)$, баранині - у 1,86 (P <0,01), козлятині - у 1,60 рази $(\mathrm{P}<0,001)$. Це пояснюється тим, що розчин натрію гідрокарбонату знешкоджує мікроор- 
ганізми на поверхні м'язової тканини. А в глибоких шарах м'яса, куди не проникає розчин натрію гідрокарбонату, вміст мікроорганізмів дещо незначно підвищувався порівняно з показниками сумнівної свіжості м'яса необробленого також на 3-4 добу реалізації за цієї ж температури (табл. 1) відповідно до виду забійних тварин: у 1,04 рази, у $0,82(\mathrm{P}<0,05)$, у 1,13 $(\mathrm{P}<0,05)$ та у 1,04 разу.

В охолодженому м'ясі забійних тварин за температури 0-6 ${ }^{\circ} \mathrm{C}$ на 3-4 добу, що було оброблено розчином натрієм гідрокарбонатом (позитивна і слабопозитивна реакції), величина $p H$ вірогідно $(\mathrm{P}<0,001)$ підвищувалась порівняно до показників сумнівної свіжості м'яса не обробленого натрієм гідрокарбонатом на 3-4 добу реалізації за цієї ж температури реалізації (табл. 1) відповідно: в яловичині - у 1,16 разу, свинині - у 1,18 , баранині - у 1,17 і козлятині - у 1,15 разу. 3i збільшенням кількості і концентрації розчину натрію гідрокарбонату (5,1\% і більше) прямопрорційно надто збільшувалася і величина $p H$ в лужний бік у свинині $(6,65 \pm 0,021)$ і баранині $(6,45 \pm 0,023)$.

Уміст МАФАнМ в охолодженому м'ясі сумнівної свіжості після оброблення розчином натрію гідрокарбонатом у кількості до 5\% (слабопозитивна реакція) мав тенденцію до зниження, але різниця була не вірогідною: у яловичині - у 1,02 рази і козлятині - у 1,05 рази порівняно до показників сумнівної свіжості м'яса не обробленого (табл. 1), де показники незначно перевищували межу нормативів доброякісного м'яса відповідно $(10,02 \pm 0,26) \times 10^{2}$ і $(10,05 \pm 0,27) \times 10^{2}$ КУО/г. А у свинині - у 1,12 рази $(\mathrm{P}<0,05)$ у баранині - у 1,08 (Р < 0,05) спостерігалося незначне вірогідне зниження вмісту КМАФАнМ за позитивної реакції за оброблення розчином натрію гідрокарбонатом, та був в межах норми для доброякісного м'яса $10^{3} \mathrm{KУО} / г$.

Але, враховуючи показники КМАФАнМ, збільшення величини $p H$ в середньому від 1,15-1,17 рази (від 6,45 до 6,65) та збільшення кількості мікроорганізмів в глибоких шарах м'язової тканини від $22 \pm 1$ до $24 \pm 1$, м’ясо можна віднести до сумнівної свіжості, яке не дозволяється випускати у вільний продаж. Тим паче, органолептика м'яса забійних тварин, яке було фальсифіковано розчином натрію гідрокарбонатом, відповідала сумнівній свіжості (темно-червоного, тьмяного кольору для яловичини, баранини і козлятини; блідо-сірого кольору у свинині, відсутність вологості на поверхні м’яса та слабокислий запах; за проби варіння мутнуватий бульйон, неприємний запах).

Необхідно також відмітити, що у охолодженій яловичині за температури від 0 до мінус $1{ }^{\circ} \mathrm{C}$ на $17-18$ добу реалізації за обробки розчином натрію гідрокарбонату (слабопозитивна реакція), кількість мікроорганізмів у поверхневих шарах порівняно до показників сумнівної свіжості (табл. 1) достовірно знизилася у $1,33$ рази ( $<<0,01)$, а у глибоких - вірогідно збільшилася у 1,06 (Р < 0,001). У охолоджених свинині, баранині, козлятині за вище вказаної температури на 1314 добу реалізації за обробки розчином натрію гідрокарбонату (слабопозитивна і позитивна реакції), кількість мікроорганізмів у поверхневих шарах достовір- но знизилася: у свинині - у 1,33 рази $(\mathrm{P}<0,01)$,баранині - у 1,75 (P $<0,001)$ та козлятині - у 1,40 рази $(\mathrm{P}<0,05)$. А у глибоких шарах м'язової тканини уміст мікроорганізмів незначно вірогідно підвищувався: у свинині - в 1,05 (P <0,01), баранині у $1,11(\mathrm{P}<0,05)$ і козлятині - у 1,24 разу $(\mathrm{P}<0,05)$.

В обробленому розчином натрію гідрокарбонату охолодженому сумнівної свіжості м'ясі всіх видів тварин величина $p H$ вірогідно $(\mathrm{P}<0,001)$ зростала, особливо в баранині (позитивна реакція - більше ніж $5 \%$ хімічного реагенту) - у 1,21 разу; а в яловичині, свинині і козлятині (слобопозитивна реакція) відповідно: у 1,17, 1,19, у 1,16 разу.

Уміст КМАФАнМ в охолодженому обробленому розчином натрію гідрокарбонату м'ясі різних видів тварин порівняно з показниками необробленого сумнівної свіжості м'яса (табл. 1) мав тенденцію до зниження, але вірогідної різниці, крім яловичини (у 1,10 разу, $(\mathrm{P}<0,05)$, не було встановлено: у свинині - у 1,11 і козлятині - у 1,4 рази, де показники незначно перевищували межу нормативів доброякісного м'яса $\left(10^{3}\right.$ КУО/г) відповідно - $(9,89 \pm 2,65) \times 10^{2},(10,03 \pm$ $3,62) \times 10^{2} \mathrm{i}(10,04 \pm 2,29) \times 10^{2} \mathrm{KУО} /$. Вміст КМАФАнМ у баранині (позитивна реакція за оброблення натрієм гідрокарбонатом) значно знижувався у 1,05 разу і був в межах нормативів. Але, враховуючи вище вказані показники, у тому числі і органолептичні, сумнівного ступеня свіжості охолодженого та обробленого натрієм гідрокарбонатом м'яса забійних тварин за температури від 0 до мінус $1{ }^{\circ} \mathrm{C}$ на $17-18$ та 13-14 добу, таке м'ясо не допускається у вільний продаж пересічному споживачеві.

Варто також зазначити, що розроблений експресний метод визначення фальсифікації м'яса забійних тварин за різні терміни реалізації та зберігання дає можливість у сукупності вищепроведених досліджень (вмісту мікроорганізмів у поверхневих і глибоких шарах м'язової тканини, величини $p H$, вмісту мезофільних аеробних і факультативно анаеробних мікроорганізмів) встановлювати безпечність та якість м'ясної сировини за реалізації на агропродовольчих ринках.

Крім того, варто вказати, що метод є експресним, простим у виконанні, а його результати дають конкретні якісні показники за наявності блідо-рожевого кольору - за відсутності обробки м'яса гідрокарбонатом натрію або наявності світло-фіолетового - за обробки м'яса гідрокарбонатом натрію із застосуванням хромового темно-синього у кількості до 5,0\% або темно-фіолетового кольору - за обробки м'яса гідрокарбонатом натрію у кількості 5,1\% і більше. Метод має перевагу перед існуючими методами визначення безпечності та якості м'яса забійних тварин в тому що вірогідність встановлення фальсифікації даних видів м'яса становить 99,9\%. Також більш вірогідні дані - у 99,0-99,5\% були отримані при порівнянні методу визначення величини $p H$ у 98,8-99,9\% до методу визначення вмісту мікроорганізмів у м'ясі забійних тварин.

За реалізації м'яса забійних тварин необхідно дотримуватися температурного та вологісного режимів 
зберігання. Так яловичину, свинину, баранину і козлятину реалізують остиглою, піддаючи після розділення туш охолодженню до температури не вище ніж $12{ }^{\circ} \mathrm{C}$; поверхня м'яса повинна мати кірочку підсихання, запах - специфічний для даного виду тварин, без сторонніх запахів. Усі види охолодженого м'яса повинні мати температуру в товщі м'язів від 0 до 4 ${ }^{\circ} \mathrm{C}$; поверхня м'яса не зволожена, м'язи пружні, запах специфічний даному виду тварин; за пробою варіння повинно відповідати свіжому ступеню. Охолоджене м'ясо забійних тварин має зберігатися у камерах зберігання за температури мінус $1{ }^{\circ} \mathrm{C}$, відносної вологості 85\% не більше ніж 12 діб (DSTU 7158:2010; HOST 1935-55); а яловичина в півтушах та четвертинах охолоджена повинна зберігатися у камерах зберігання за температури від 0 мінус $1{ }^{\circ} \mathrm{C}$, відносної вологості 85\% не більше 16 діб (DSTU 6030:2008).

Фальсифікація м'яса забійних тварин є соціальною проблемою в Україні. Тому інспекторам ветеринарної медицини необхідно за здійснення заходів державного контролю відповідності діяльності операторів ринку, до яких належить агропродовольчий ринок, вимогам законодавства про харчові продукти, враховувати хімічний ризик, який пов'язаний із фальсифікацією м'яса забійних тварин, оцінювати ступінь цього ризику, запроваджуючи систему простежуваності, систему TACCP (Stybel \& Simonov, 2018) щодо запобігання шкідливим загрозам для харчових продуктів, і впроваджувати заходи управління цими загрозами, джерелом яких є навмисне забруднення шкідливими токсичними речовинами.

\section{Висновки}

3 метою реалізації доброякісного м'яса забійних тварин на агропродовольчих ринках - яловичини, свинини, баранини, козлятини та дотримання належних санітарно-гігієнічних вимог здійснювати державний контроль за виникненням хімічного ризику, оцінювати його та запобігати виникненню фальсифікації, використовуючи розроблений та апробований експресний метод, який достовірний у 99,9\%, контролювання м'ясної сировини на предмет іiі фальсифікації розчином натрію гідрокарбонату за застосування спиртового розчину хромового темно-синього 3 масовою концентрацією $0,5 \%$.

1. Установлено фальсифікацію м'яса забійних тварин розчином натрію гідрокарбонату на 3-4 добу реалізації за температури від 0 до $6^{\circ} \mathrm{C}$ : у яловичині і козлятині - слабопозитивну реакцію (до 5\%), у свинині і баранині позитивну $(5,1 \%$ і більше). Установлено фальсифікацію м'яса забійних тварин розчином натрію гідрокарбонату на 17-18 (для яловичини) і 1314 добу реалізації за температури від 0 до мінус $1{ }^{\circ} \mathrm{C}$ : у яловичині, свинині й козлятині - слабопозитивну реакцію (до 5\%), у баранині позитивну (5,1\% і більше).

2. Установлено вплив натрію гідрокарбонату на якість та безпечність м'яса забійних тварин на 3-4 добу реалізації за температури $0-6{ }^{\circ} \mathrm{C}$ : вірогідно зме- ншувався уміст мікроорганізмів у поверхневих шарах яловичини - у 1,56 разу $(\mathrm{P}<0,01)$, свинини $-\mathrm{y} 1,87$ $(\mathrm{P}<0,001)$, баранини - у 1,86 ( $<<0,01)$, козлятини $-\mathrm{y}$ 1,60 рази $(\mathrm{P}<0,001)$; а вміст мікроорганізмів у глибоких шарах дещо незначно вірогідно (крім яловичини) підвищувався відповідно до виду забійних тварин: у 1,04 рази, у $0,82(\mathrm{P}<0,05)$, у $1,13(\mathrm{P}<0,05)$ та у 1,04 разу. Величина $p H$ вірогідно $(\mathrm{P}<0,001)$ підвищувалась і становила: у свинині - 6,61 \pm 024 , баранині в $6,65 \pm 02$ за позитивної реакції та в яловичині - у $6,56 \pm 0,020$, козлятині - в 6,45 $\pm 0,023$ за слабо позитивної реакції. Уміст МАФАнМ мав тенденцію до зниження, але різниця була не вірогідною: у яловичині у 1,02 разу і козлятині - у 1,05 разу, де показники незначно перевищували межу нормативів доброякісного м'яса відповідно $(10,02 \pm 0,26) \times 10^{2} \mathrm{i}(10,05 \pm$ $0,27) \times 10^{2} \mathrm{KУO} /$; а в свинині - в 1,12 разу $(\mathrm{P}<0,05)$ у баранині - у 1,08 (Р < 0,05), спостерігалося незначне вірогідне зниження вмісту КМАФАнМ за позитивної реакції і був у межах норми для доброякісного м'яса $10^{3} \mathrm{KУO} / \Gamma$.

3. Установлено вплив натрію гідрокарбонату на якість та безпечність м'яса забійних тварин на 17-18 (для яловичини) і на 13-14 добу реалізації за температури від 0 до мінус $1^{\circ} \mathrm{C}$ : вірогідно зменшувався вміст мікроорганізмів у поверхневих шарах яловичини $\mathrm{i}$ свинини у 1,33 разу ( $\mathrm{P}<0,001)$, баранини - у 1,75 $(\mathrm{P}<0,01)$, козлятини - у 1,40 разу $(\mathrm{P}<0,05)$; а вміст мікроорганізмів у глибоких шарах дещо незначно вірогідно підвищувався відповідно до виду забійних тварин: у 1,04 разу, в 0,82 (P < 0,05), у 1,13 (P < 0,05) та у 1,04 разу. Величина $p H$ вірогідно $(\mathrm{P}<0,001)$ підвищувалась і становила: у яловичині $-6,57 \pm 0,017$, свинині $-6,72 \pm 0,018$, козлятині - у 6,53 $\pm 0,022$ за слабопозитивної реакції та у баранині - у 6,85 $\pm 0,021$ за позитивної реакції Уміст МАФАнМ мав тенденцію до зниження, але вірогідної різниці, крім яловичини (у 1,10 разу, ( $<$ 0,05), не було встановлено: у свинині - в 1,11 і козлятині - у 1,4 разу, де показники незначно перевищували межу нормативів доброякісного м'яса $\left(10^{3} \mathrm{KУО} / г\right)$ відповідно - $(9,89 \pm 2,65) \times 10^{2}$, $(10,03 \pm 3,62) \times 10^{2} \mathrm{i}(10,04 \pm 2,29) \times 10^{2} \mathrm{KУО} / г$; а у баранині (позитивна реакція) значно знижувався у 1,05 разу i був у межах нормативів $9,87 \pm 0,27 \times 10^{2} \mathrm{KУО} / \Gamma$.

Перспективи подальших досліджень. Встановити хімічний склад м'яса забійних тварин (вміст білка, жиру, сухої речовини, золи тощо) за обробки їх розчином натрію гідрокарбонатом.

\section{References}

Bohatko, N.M., Fotina, T.I., \& Yatsenko, I.V. (2019). Sposib vyznachennia falsyfikatsii miasa zabiinykh tvaryn, za obrobky hidrokarbonatom natriiu iz zastosuvanniam khromovoho temno-synoho: patent Ukrainy na korysnu model 132813, MPK G01N 33/12 (2006.01). № u 2018 10106; zaiavl. 10.10.2018; opubl. 11.03.2019, Biul. № 5. 4 s. (in Ukrainian). 
Comaposada, J., Gou, P., \& Arnau, J. (2000). The effect of sodium chloride content and temperature on pork meat isotherms. Meat Science, 55(3), 291-295. doi: 10.1016/S0309-1740(99)00154-0.

DSTU 2917-2001 (ISO 2917: 1999, IDT). Miaso ta miasni produkty. Vymiriuvannia $\mathrm{rN}$ - kontrolnyi metod: [Ofitsiinyi nakaz 2003-10-01]. K.: Derzhavnyi komitet Ukrainy z pytan tekhnichnoho rehuliuvannia ta spozhyvchoi polityky, 2002. 6 s. (in Ukrainian).

DSTU 6030:2008. Miaso. Yalovychyna i teliatyna $v$ tushakh, napivtushakh i chetvertynakh. Tekhnichni umovy. [Ofitsiinyi nakaz 2009-04-01]. Kyiv: Derzhspozhyvstandart Ukrainy, 2009. 13 s. (in Ukrainian).

DSTU 7158:2010. Miaso. Svynyna v tushakh i napivtushakh. Tekhnichni umovy [Ofitsiinyi nakaz 2011-01-01]. Kyiv: Derzhspozhyvstandart Ukrainy, 2011. 11 s. (in Ukrainian).

DSTU ISO 4833:2006 (ISO 4833: 2003, IDT). Mikrobiolohiia kharchovykh produktiv i kormiv dlia tvaryn. Horyzontalnyi metod pidrakhunku mikroorhanizmiv. Tekhnika pidrakhunku kolonii pry temperaturi $30 \mathrm{~S}$. [Ofitsiinyi nakaz 2007-10-01]. Kyiv: Derzhspozhyvstandart Ukrainy, 2008. 7 s. (in Ukrainian).

Dyrektyva Rady YeS 94/65/EC vid 14.12.1994 roku, yaka vstanovliuie vymohy, shcho zastosovuiutsia do vyrobnytstva ta realizatsii podribnenoho miasa (farshu) ta miasnykh produktiv. http://www.reachteam.eu/chinese/REACH-

ME/engine/sources/directiva the radiation-65-1994EC.html (in Ukrainian).

HOST 1935-55. Miaso baranyny ta kozliatyny v tushakh. Tekhnichni umovy [Ofitsiinyi nakaz 2011-01-01]. Kyiv: Derzhspozhyvstandart Ukrainy, 2011. 11 s. (in Ukrainian).

HOST 23392-2016. Miaso. Metody khimichnoho ta mikroskopichnoho analizu svizhosti. [Data vvedennia 1980-01-01]. Zmina 18.10.2016. M.: Standartinform, 2016. 7 s. (in Ukrainian).

HOST 7269-2006. Miaso. Metody vidboru prob ta orhanoleptychni metody vyznachennia svizhosti [Data vveden-nia 1980-01-01]. Zmina 18.10.2006. M.: Standartinform, 2016. 7 s. (in Ukrainian).

Hulebak, K.L., \& Schlosser, W.J. (2012). Hazard analysis andcritical control point $(H A C C P)$ history and conceptual over view. Risk analysis, 22(3), 547-552. doi: 10.1111/0272-4332.000383.

Ivchenko, V.M., Sharandak, V.V., Horbatiuk, O.I., \& Denysiuk, H.M. (2006). Dovidnyk mikrobiolohichnykh metodiv doslidzhennia kharchovykh produktiv i kormiv dlia tvaryn zghidno z mizhnarodnymy standartamy. Bila Tserkva (in Ukrainian).

Kononskyi, O.I. (2006). Biokhimiia tvaryn. Kyiv: Vyshcha shkola (in Ukrainian).

Mizobe, M., Senokuchi, V., \& Jki, K. (2000). The intehrated sanitation management system including HACCP in the Japanese porting meat plant. J. Japan Vet. Med. Assn, 53(3), 607-614.

Postanova Kabinetu Ministriv Ukrainy vid 31.10. 2018. № 896. Poriadok vyznachennia periodychnosti ta vykonannia planovykh zakhodiv derzhavnoho kontroliu za dotrymanniam operatoramy rynku vymoh zakonodavstva pro kharchovi produkty, kormy, zdorovia ta dobrobut tvaryn, shcho zdiis-niuietsia Derzhavnoiu sluzhboiu zakhystu produktiv kharchuvannia ta spozhyvachiv, ta kryterii, za yakymy otsiniuietsia stupin ryzyku yoho realizatsii (in Ukrainian).

Pravyla peredzabiinoho veterynarnoho ohliadu tvaryn ta veterynarno-sanitarnoi ekspertyzy miasa ta miasnykh produktiv: Nakaz Derzhavnoho departamentu veterynarnoi medytsyny vid 21.06 .2002 r. № 28.46 s. (in Ukrainian).

Pro derzhavnyi kontrol za dotrymanniam zakonodavstva pro kharchovi produkty, kormy, pobichni produkty tvarynnoho pokhodzhennia, zdorovia ta blahopoluchchia tvaryn: Zakon Ukrainy vid 18.05.2017 r. № 2042-VIII, 2017. https://zakon.rada.gov.ua/laws/show/2042-viii (in Ukrainian).

Rehlament (IeS) Yevropeiskoho Parlamentu i Rady vid 28 sichnia 2002 roku № 178/2002 shchodo vstanovlennia zahalnykh pryntsypiv i vymoh zakonodavstva pro kharchovi produkty,stvorennia Yevropeiskoho Ahentstva $\mathrm{z}$ pytan bezpechnosti kharchovykh produktiv i vstanovlennia protsedur u pytanniakh, poviazanykh iz bezpechnistiu kharchovykh produktiv. http://www.reachteam.eu/chinese/REACHME/engine/sources/regulations/launch-178-2002EC.html (in Ukrainian).

Rehlament (IeS) Yevropeiskoho Parlamentu i Rady vid 29 kvitnia 2004 roku № 852/2004 Pro hihiienu kharchovykh produktiv. https://eur-lex.europa.eu/legalcontent/EN/TXT/?uri=CELEX\%3A32004R0852 (in Ukrainian).

Stybel, V., \& Simonov, M. (2018). Upravlinnia bezpekoiu kharchovykh produktiv: praktychnyi posibnyk. Lviv, Tzov: Halytska vydavnycha spilka (in Ukrainian).

Tsekhmistrenko, S.I., \& Tsekhmistrenko, O.S. (2014). Biokhimiia miasa i miasoproduktiv: navchalnyi posibnyk. Bila Tserkva (in Ukrainian). 